\title{
Effect of Microwave and Steam Treatment on the Thermo- Hygro-Plasticity of Beech Wood
}

\author{
Jakub Dömény, ${ }^{\mathrm{a}, *}$ Martin Brabec, ${ }^{\mathrm{a}}$ Radim Rousek, ${ }^{\mathrm{a}}$ Lauri Rautkari, ${ }^{\mathrm{b}}$ and Petr Čermák ${ }^{\mathrm{a}}$ \\ The effects of microwave and steam treatment were analyzed relative to the \\ immediate (thermo-hygro-plasticity) and post-assessed (permanent changes) \\ properties of wood. The study was conducted using European beech (Fagus \\ sylvatica L.) standard and 1.5 times up-scaled (only for microwave-heated and \\ reference samples) bending specimens tested in a static three-point loading \\ mode. The specimens were plasticized by heat and moisture (1) separately and \\ (2) simultaneously by heating moist specimens using (i) various microwave \\ regimes in continuous mode, and (ii) heated saturated steam in discontinuous \\ mode. Oven-dried specimens tested at $20^{\circ} \mathrm{C}$ served as references. The \\ thermo-hygro-plasticity was studied immediately after treatment, whereas the \\ permanent changes were assessed after oven-drying of plasticized specimens \\ to $0 \%$ moisture content. Permanent structural changes were analyzed using \\ scanning electron microscopy. Microwave treatment increased the plasticity of \\ wood (decreasing the modulus of elasticity by $70 \%$ ) comparably to steam \\ treatment, when the output moisture content was $30 \%$ or higher. A similar \\ degree of plasticity was found in up-scaled specimens heated by microwaves. \\ Further analyses confirmed that microwave treatment did not cause any \\ permanent damage to wood structure or reduce mechanical performance. The \\ results showed that microwave treatment is an efficient alternative to steaming \\ when plasticizing moist wood.
}

Keywords: Wood plasticization; Microwave treatment; Steam treatment; Bending strength;

Bending stiffness; Deflection

Contact information: a: Department of Wood Science and Technology, Faculty of Forestry and Wood Technology, Mendel University in Brno, Zemédělská 3, 61300 Brno, Czech Republic; b: Department of Bioproducts and Biosystems, School of Chemical Engineering, Aalto University, P.O. Box 16300, FI-00076 Aalto, Finland; *Corresponding author: jakub.domeny@mendelu.cz

\section{INTRODUCTION}

Wood is a natural, sustainable, and renewable material with great importance for a number of industrial sectors, such as building construction, furniture, interior design, packaging, and chemicals (Rowell 2005). This multipurpose material may need to be reshaped in order to acquire the desired functionality of a wood-based product (Navi and Sandberg 2012). For optimum structural performance, it is preferable to make the final shape by a chip-less forming method such as bending or shaping. These are ancient crafts that are important in many current wood-working industries, especially the manufacture of furniture, boats and ships, musical instruments, agricultural implements, tool handles, and sporting goods (Sandberg et al. 2013).

In the middle of the $18^{\text {th }}$ century, Michael Thonet established an effective technique for wood bending, which involved plasticizing the moist wood by saturated steam pretreatment, followed by drying to stabilize the desired shape (Norimoto and Gril 1989). The Thonet plasticization procedure is a hydro-thermal treatment resulting in considerably 
decreased stiffness accompanied by increased plasticity of wood, which becomes easier to deform (Dömény et al. 2018). Applying the appropriate amount of heat and water in the right way causes softening of the wood structure consisting of the three bio-polymers, cellulose, hemicelluloses, and lignin (Rautkari et al. 2010). The softening is characterized by a phase transition of the lignin and partially hemicellulose matrix from glassy to rubbery (Lamason and Gong 2007). The phase transition of the matrix occurs when the glass transition temperature $\left(T_{\mathrm{g}}\right)$ is reached. At $T_{\mathrm{g}}$, inter- and intra-molecular cohesive forces in the wood (Van der Waals forces, hydrogen bonds) decrease in their influence, which allows molecular chains to slide past each other (the cooperative motion of large segments of atoms along a polymer backbone) when a force is applied (Navi and Sandberg 2012; Jakes et al. 2019). Moreover, water molecules cause hydrogen bonds to break in wood polymers (Goring 1963). The $T_{\mathrm{g}}$ is affected by the morphological arrangement, chemical interaction between wood components, and moisture content (MC) (Back and Salmén 1982). Increasing the MC dramatically decreases the $T_{\mathrm{g}}$ of lignin, until the wood reaches its fiber saturation point (FSP) (Börcsök and Pásztory 2021).

Steam as a traditionally used plasticization medium transfers the heat by convection to the wood surface, from where it is conducted into the wood core (Plumb et al. 1985; Rémond et al. 2007). Conductive heat transfer occurs spontaneously due to the non-zero temperature gradient within the wood structure and is affected by the MC, density, temperature, extractive content, grain direction, fibril angle, and structural irregularities (Kollmann and Côté 1984). A large amount of energy and prolonged heating are required before the desired temperature is reached throughout the cross-section of wood, which leads to low production efficiency and high cost products. Therefore, more efficient ways to heat the wood structure have been investigated. The most promising is microwave (MW) treatment (Norimoto and Gril 1989; Seyfarth et al. 2003; Vongpradubchai and Rattanadecho 2009; Gašparík and Gaff 2013; Dömény et al. 2014, 2018).

Less energy consumption, faster heating throughout the wood structure, and easier adaptability for continuous processes are the key benefits of MW treatment compared with conventional heating by steam (Vongpradubchai and Rattanadecho 2009; Gašparík and Gaff 2013). MW radiation takes the form of self-propagating waves in a vacuum or in a mass. These waves induce a magnetic and electric field. The influence of the magnetic field on the wood is negligible, because the absorption of magnetic field energy in dielectric materials, such as wood, is very low, comparable to that of air (Torgovnikov 1993). In contrast, the absorption by dielectric materials of electric field energy is considerably higher. The energy of an electric field is absorbed by polar molecules $\left(\mathrm{H}_{2} \mathrm{O},-\mathrm{OH},-\mathrm{CH}_{2} \mathrm{OH}\right.$, $-\mathrm{CHOH},-\mathrm{COOH})$, which consume the energy by rotating in the alternating electric field (Metaxas and Meredith 1983; Torgovnikov 1993; Hansson and Antti 2003). The cohesiveness of the wood structure causes frictional heat, and therefore the high frequency electromagnetic waves, including those in the MW spectrum, interact with the wood by producing internal heat (Makovíny 2000; Hansson and Antti 2003). The production of internal heat in a MW field rapidly increases when the wood contains water as a polar substance, which, together with heat, is crucial for wood plasticization. The internal heat released from the wood structure to the surrounding atmosphere takes moisture away, causing wood drying to take place. The decrease in moisture content, especially under FSP, increases the $T_{\mathrm{g}}$ and reduces the wood plasticity (Zielonka et al. 1997; Oliveira and Franca 2002; Feng and Chen 2008).

MW treatment may degrade the mechanical properties of wood (Oloyede and Groombridge 2000; Hansson and Antti 2003; Hong-Hai et al. 2005; Leiker et al. 2005; 
Machado 2006). Torgovnikov and Vinden (2009) stated that when applying MW treatment to wood with a certain $\mathrm{MC}$, the water molecules in the cell walls absorbed energy, vaporized, and formed high-pressure steam in the wood structure. This could consequently lead to the delamination of cell walls. Li et al. (2009) stated that high-intensity MW treatment created high internal steam pressure in wood cell lumens, leading to high-tensile stress in cell walls or intercellular layers. When the tensile stress in cell walls or intercellular layers is greater than its tensile strength, micro-cracks occur. However, Antti et al. (2001) mentioned that if appropriate MW power is used during the treatment, there are no statistically significant changes in mechanical properties. Therefore, it is important to analyze microstructural changes and the mechanical properties of wood after $\mathrm{MW}$ treatment.

MW heating is not yet used industrially, and heating parameters need to be optimized. The present study aims to (1) analyze the influence of selected MW heating parameters, including specimen size, on wood plasticity, (2) compare the plasticization efficiency when MW and steam treatment are used, and (3) assess any permanent changes in structure and bending properties caused by MW treatment. It is hypothesized that by using appropriate MW heating parameters, wood plasticity equal to that obtained by steam treatment can be achieved. Therefore, this work should provide better insights into the details of wood plasticization using MW treatment and its potential use on an industrial scale.

\section{EXPERIMENTAL}

European beech (Fagus sylvatica L.) wood, with an average oven-dry density of $647 \mathrm{~kg} / \mathrm{m}^{3}$, from a Czech forest enterprise was studied. Specimens of dimensions $20 \times 20 \times 300 \mathrm{~mm}$ (standard specimens), and $30 \times 30 \times 450 \mathrm{~mm}$ (up-scaled specimens) were cut from a single board with the grown right parallel to the longest specimen edge but with varying grain orientation within the specimen's cross section. The standard specimens were sorted into eight groups with 15 specimens in each group, and the up-scaled specimens were placed into two groups with 20 and 40 specimens, respectively. Specimens were treated according to the parameters presented in Table 1. As the MW heating of wood is accompanied by considerable moisture content changes, the wood plasticized by steam and microwaves would have a very different moisture content. Therefore, also the influence of single factors (i.e., moisture content and temperature) on wood plasticity were analyzed within the study. Zero initial moisture content (MC) was achieved by drying specimens at $103{ }^{\circ} \mathrm{C}$ for $48 \mathrm{~h}$ (standard specimens), and $72 \mathrm{~h}$ (up-scaled specimens). Initial MC of $\pm 30 \%$ (only standard specimens) was achieved after three weeks of conditioning in a climate chamber with $99 \%$ relative humidity $(\mathrm{RH})$ environment. Specimens with an initial MC of $60 \%$ were immersed in water for about eight (standard specimens), or 10 (upscaled specimens) days. All specimens were regularly weighed in order to achieve an equal initial MC within the testing group.

Microwave treatment of wood was carried out using a continuous pilot laboratoryscale device (ROmiLL, spol. s r.o, Brno, Czech Republic), which operated at a frequency of $2.45 \mathrm{GHz}$ and provided adjustable MW power from 0.6 to $5 \mathrm{~kW}$. Specimens were treated with MW power of 1.5 and $3.5 \mathrm{~kW}$ at a conveyer speed of 0.13 to $0.37 \mathrm{~m} / \mathrm{min}$ (Table 1 ) in a standard laboratory climate. 
Table 1. Target Initial, Plasticization, and Testing Parameters of MW and Steam Treatment for Individual Testing Groups

\begin{tabular}{|c|c|c|c|c|c|c|c|}
\hline & \multicolumn{2}{|c|}{ Initial Parameters } & \multicolumn{3}{|c|}{ Plasticization Parameters } & \multicolumn{2}{|c|}{ Testing Parameters } \\
\hline $\begin{array}{l}\text { Testing } \\
\text { groups }\end{array}$ & $\begin{array}{c}\text { Temp. } \\
\left({ }^{\circ} \mathrm{C}\right)\end{array}$ & $\begin{array}{c}\text { Moisture } \\
\text { content } \\
(\%) \\
\end{array}$ & $\begin{array}{l}\text { MW } \\
\text { power } \\
(\mathrm{kW})\end{array}$ & \begin{tabular}{|c} 
Conveyer \\
speed \\
(m/min)
\end{tabular} & $\begin{array}{l}\mathrm{RH} \\
(\%)\end{array}$ & $\begin{array}{c}\text { Temp. } \\
\left({ }^{\circ} \mathrm{C}\right)\end{array}$ & $\begin{array}{c}\text { Moisture } \\
\text { content } \\
(\%)\end{array}$ \\
\hline & \multicolumn{7}{|c|}{ Standard specimens of dimensions $20 \times 20 \times 300 \mathrm{~mm}$} \\
\hline Ref $_{1}$ & 20 & 0 & & & & \pm 20 & 0 \\
\hline $\operatorname{Ref}_{2}$ & 80 & 0 & & & & \pm 80 & 0 \\
\hline Ref $_{3}$ & 20 & \pm 30 & & & & \pm 20 & \pm 30 \\
\hline Steam & 20 & \pm 30 & & & 99 & \pm 80 & \pm 30 \\
\hline $\mathrm{MW}_{\mathbf{1}}$ & 20 & \pm 60 & 1.5 & 0.13 & & \pm 80 & \pm 20 \\
\hline $\mathrm{MW}_{2}$ & 20 & \pm 60 & 1.5 & 0.20 & & \pm 80 & \pm 30 \\
\hline $\mathrm{MW}_{3}$ & 20 & \pm 60 & 1.5 & 0.27 & & \pm 80 & \pm 40 \\
\hline $\mathbf{M W}_{4}$ & 20 & \pm 60 & 3.5 & 0.37 & & \pm 80 & \pm 30 \\
\hline & \multicolumn{7}{|c|}{ Up-scaled specimens of dimensions $30 \times 30 \times 450 \mathrm{~mm}$} \\
\hline Ref $_{4}$ & 20 & 0 & & & & \pm 20 & 0 \\
\hline $\mathrm{MW}_{5}$ & 20 & \pm 60 & 1.5 & 0.1 & & \pm 80 & \pm 30 \\
\hline
\end{tabular}

Standard deviations in parentheses

Microwave treatment process parameters (MW power, conveyer speed) were selected to achieve target testing MC, i.e., $\pm 20 \%$ (below FSP), $\pm 30 \%$ (approx. at FSP), and $\pm 40 \%$ (above FSP) and target temperature, i.e., $\pm 80{ }^{\circ} \mathrm{C}$. Steam treatment was carried out using a laboratory autoclave at saturated steam environment with atmospheric pressure and temperature of $80^{\circ} \mathrm{C}$ for $1 \mathrm{~h}$. After $\mathrm{MW}$ and steam treatment, the surface temperature and $\mathrm{MC}$ of all specimens were determined. The surface temperature was measured using a contactless infrared thermometer (IR-380, Voltcraft), and the MC was determined by weighing the specimens. According to the results obtained by testing the standard specimens, only the most appropriate MW regime (MW power of $1.5 \mathrm{~kW}$ and conveyer speed of $0.2 \mathrm{~m} / \mathrm{min}$ ) was up-scaled to the larger specimens by reducing the conveyer speed to half (Table 1). The plasticity of specimens was determined immediately after measuring the surface temperature and weighing on all steamed specimens and 10 standard, and 20 up-scaled specimens, from each MW treatment group. Five standard and 20 up-scaled oven-dried specimens from each MW treatment group were examined for structural changes caused by MW treatment.

Wood plasticity was determined immediately after the treatment using a static three-point bending (flexural) test with the crosshead speed of $23 \mathrm{~mm} / \mathrm{min}$. The modulus of elasticity (MOE), modulus of rupture (MOR), and maximum deflection as a percentage of the support span $\left(y_{\text {perc }}\right)$ before specimen failure were taken as characteristics for the plasticity assessment. The bending test was carried out using a universal testing machine, Zwick Z050/TH 3A (Zwick Roell AG, Ulm, Germany), according to ČSN 490115 (1979) and ČSN 490116 (1986) for MOR and MOE, respectively. The force was applied and measured using a $50 \mathrm{kN}$ load cell until failure. Failure, recognized by a significant drop in the force $(60 \%)$ and visible sign of failure, occurred between $30 \mathrm{~s}$ and $60 \mathrm{~s}$. 
The radius of supports and loading heads was $15 \mathrm{~mm}$. The support span was determined as $12 \times$ specimen height oriented in the load direction, i.e., $12 \times 20=240 \mathrm{~mm}$ for standard specimens, and $12 \times 30=360 \mathrm{~mm}$ for up-scaled specimens, whereas the free specimens' ends were equal to $1.5 \times$ specimen height, i.e., $1.5 \times 20=30 \mathrm{~mm}$, and $1.5 \times 30$ $=45 \mathrm{~mm}$ respectively. The modulus of rupture (MOR) and modulus of elasticity (MOE) were calculated according to Equations 1 and 2 respectively:

$$
\operatorname{MOR}=\frac{F_{\max } \cdot L_{S}}{b \cdot h^{2}}
$$

where $F_{\max }$ is the maximum loading force, $L_{S}$ is the support span, $b$ is the dimension of a cross-section perpendicular to the load direction and $h$ is the dimension of a cross-section parallel to the load direction.

$$
\text { MOE }=\frac{\left(F_{40 \%}-F_{10 \%}\right) \cdot L_{S}^{3}}{4 \cdot b \cdot h^{3} \cdot\left(y_{40 \%}-y_{10 \%}\right)}
$$

In Eq. 2, $F_{40 \%}$ and $F_{10 \%}$ are the forces at the $40 \%$ and $10 \%$ level of the maximum loading force $F_{\max }$, and $y_{40 \%}$ and $y_{10 \%}$ are the deflections measured by the clip-on deflectometer at forces $F_{40 \%}$ and $F_{10 \%}$.

The permanent changes in structure and mechanical properties caused by MW treatment were investigated on the other five standard and 20 up-scaled specimens from each MW treatment group by means of microscopy analysis and by the same bending procedure. After MW treatment, these other specimens were oven-dried in increasing temperature steps, ending with $103{ }^{\circ} \mathrm{C}$, until an $\mathrm{MC}$ of $0 \%$ was reached. The structural changes were quantified by comparing the results and the microscopic structures of the MW-treated specimens, i.e., $\mathrm{MW}_{1}$ (long time exposure, $0.13 \mathrm{~m} / \mathrm{min}$ ), $\mathrm{MW}_{4}$ (high power exposure, $3.5 \mathrm{~kW}$ ), and appropriate reference specimens $\left(\operatorname{Ref}_{2}\right)$. The microscopy analysis was done by using a scanning electron microscopy technique. Standard samples from specimens $\left(4 \times 4 \times 4 \mathrm{~mm}^{3}\right)$ were softened with water, cut with a sledge microtome and dried at room conditions. The samples were sputter coated with gold using a LUXOR ${ }^{\mathrm{TM}}$ gold coater (APTCO Group, Nazareth, Belgium). The layer thickness was $15 \mathrm{~nm}$. The cross section was observed with an SEM Tescan Vega 4 (TESCAN ORSAY HOLDING, a. s., Brno, Czech Republic). The scans were prepared in resolution scanning mode in a high vacuum using a detector of secondary electrons (SE detector). The best image quality was obtained with these settings: landing energy $7 \mathrm{keV}$, beam current $50 \mathrm{pA}$, scan speed 5 (10 $\mu$ s/pixel), and image resolution 3,072 × 2,304 pixels. The microscope magnification was set to 2,000x. The images of the samples obtained were compared.

The data were processed and graphed in OriginPro (OriginPro 9.0., OriginLab, Northampton, MA, USA) and evaluated using the Shapiro-Wilk test, and one-factor analysis of variance (ANOVA), completed with Tukey's honest significance test (HSD). Statistically significant differences were considered at $\mathrm{p} \leq 0.05$. Statistical tests were performed separately for standard and up-scaled specimens. Up-scaled specimens were evaluated using T-tests, with regards to the comparison of two testing groups. The data of all groups in Fig. 1 were averaged using an Average Multiple Curves function to present representative curves for each testing group. The error bars in Fig. 2, 3, and 4 present the standard deviation values. 


\section{RESULTS AND DISCUSSION}

\section{Temperature and Moisture Content of Specimens}

The values of the on-site-measured initial, plasticization, and testing parameters of the reference, MW, and steam-treated specimens are presented in Table 2 . The equilibrium moisture content (EMC) of the tested specimens, measured at $99 \%$ relative humidity, was on average $25.0 \%$ for the Ref 3 and steam-heated groups. These values are in agreement with results reported by Požgaj et al. (1997) and Baar et al. (2021), who reported 27.9\% and $27.4 \%$, respectively. Minor differences between these two groups, determined at FSP, were considered negligible for the present study, i.e., falling within the margin of error.

Table 2. Measured Initial, Plasticization, and Testing Parameters of MW and Steam Treatment for Individual Testing Groups

\begin{tabular}{|c|c|c|c|c|c|c|c|c|c|c|}
\hline \multirow{2}{*}{\begin{tabular}{|l|} 
Testing \\
groups
\end{tabular}} & \multirow[b]{2}{*}{$\begin{array}{c}\rho_{0} \\
\left(\mathrm{~kg} / \mathrm{m}^{3}\right)\end{array}$} & \multirow[b]{2}{*}{$\begin{array}{l}\text { No. of } \\
\text { spec. }\end{array}$} & \multicolumn{2}{|c|}{$\begin{array}{c}\text { Initial } \\
\text { Parameters } \\
\end{array}$} & \multicolumn{4}{|c|}{ Plasticization Parameters } & \multicolumn{2}{|c|}{$\begin{array}{c}\text { Testing } \\
\text { Parameters }\end{array}$} \\
\hline & & & $\begin{array}{c}\text { Temp. } \\
\left({ }^{\circ} \mathrm{C}\right)\end{array}$ & $\begin{array}{c}\text { Moisture } \\
\text { content } \\
(\%)\end{array}$ & $\begin{array}{l}\text { MW } \\
\text { power } \\
(\mathrm{kW})\end{array}$ & $\begin{array}{l}\text { Conveyer } \\
\text { speed } \\
(\mathrm{m} / \mathrm{min})\end{array}$ & $\begin{array}{c}\text { MW } \\
\text { energy } \\
\left(\mathrm{kWh} / \mathrm{m}^{3}\right)\end{array}$ & \begin{tabular}{|l}
$\mathrm{RH}$ \\
$(\%)$
\end{tabular} & $\begin{array}{l}\text { Temp. } \\
\left({ }^{\circ} \mathrm{C}\right)\end{array}$ & \begin{tabular}{|c|} 
Moisture \\
content \\
$(\%)$
\end{tabular} \\
\hline & \multicolumn{10}{|c|}{ Standard specimens of dimensions $20 \times 20 \times 300 \mathrm{~mm}$} \\
\hline Ref $_{1}$ & $640(24)$ & 15 & 20 & 0 & & & & & $20 \mathrm{a}$ & $0 \mathrm{a}$ \\
\hline $\operatorname{Ref}_{2}$ & $641(25)$ & 15 & 80 & 0 & & & & & $80 \mathrm{~b}$ & $0 \mathrm{a}$ \\
\hline $\operatorname{Ref}_{3}$ & $641(25)$ & 15 & 20 & $25(2.8)$ & & & & & $20 \mathrm{a}$ & $25(2.8) b$ \\
\hline Steam & $643(25)$ & 15 & 20 & $25(1.4)$ & & & & 99 & $76(3.7) b$ & $32(2.3) \mathrm{c}$ \\
\hline $\mathbf{M W}_{1}$ & $644(24)$ & $10+5$ & 20 & $62(2.5)$ & 1.5 & 0.1 & 480.8 & & $83(4.7) \mathrm{c}$ & $22(0.8) b$ \\
\hline $\mathrm{MW}_{2}$ & $654(31)$ & $10+5$ & 20 & $63(5.0)$ & 1.5 & 0.20 & 312.5 & & $78(3.3) b$ & $36(3.7) \mathrm{c}$ \\
\hline $\mathrm{MW}_{3}$ & $657(26)$ & $10+5$ & 20 & $60(1.8)$ & 1.5 & 0.27 & 231.5 & & $77(3.1) b$ & $42(6.0) d$ \\
\hline $\mathrm{MW}_{4}$ & $654(32)$ & $10+5$ & 20 & $63(3.4)$ & 3.5 & 0.37 & 394.1 & & $74(3.8) b$ & $32(3.0) c$ \\
\hline & \multicolumn{10}{|c|}{ Up-scaled specimens of dimensions $30 \times 30 \times 450 \mathrm{~mm}$} \\
\hline $\operatorname{Ref}_{4}$ & $618(25)$ & 20 & 20 & 0 & & & & & $20 \mathrm{~A}$ & $0 \mathrm{~A}$ \\
\hline $\mathrm{MW}_{5}$ & $621(24)$ & $20+20$ & 20 & $55(3.7)$ & 1.5 & 0.1 & 277.8 & & $73.1(2.3) \mathrm{B}$ & $29.4(3.8) \mathrm{B}$ \\
\hline
\end{tabular}

Standard deviations in parentheses. The same letters within the testing group indicate that the difference between the means is not significant at the 0.05 level.

The initial MC of specimens intended for microwave treatment reached on average $62 \%$ after 8 to 10 days of water immersion. When higher MW power $(3.5 \mathrm{~kW})$ and increased conveyer speed were applied $\left(\mathrm{MW}_{4}\right)$, the MCs achieved were comparable with $\mathrm{MW}_{2}$. The up-scaled specimens (MW5) reached on average 55\% of initial MC and, after MW treatment, achieved $29.4 \%$ of MC. The average testing temperature of all MW-heated specimens achieved $\pm 80{ }^{\circ} \mathrm{C}$ as a result of steam evaporation during MW treatment. The differences between target and measured temperatures and MCs (see Table 1 and Table 2) may be explained by non-accurate tuning of the proposed steam and MW regimes and variability between specimen properties (density, number of annual rings, etc.). However, the temperature and $\mathrm{MC}$ of specimens measured after steam and MW treatment were sufficient with regards to the study goals.

\section{Wood Plasticity}

Average force-deflection curves are plotted in Fig. 1. The force-deflection curves clearly show a considerably longer non-linear part from the proportional limit to the 
maximum force, for steam- (Steam) and MW-heated (MW $\left.\mathrm{MW}_{1-4}\right)$ specimens compared with the reference $\left(\operatorname{Ref}_{1-3}\right)$ ones. As the non-linear part of the force-deflection curve characterizes the permanent displacement of internal wood bonds, greater plasticity of the steam- and MW-heated specimens compared to the reference specimens was shown. The considerably slower drop of the force observed for the steam- and MW-heated compared to reference specimens, when the maximum force was reached, indicates reduced brittleness as another plasticity feature. According to Navi and Sandberg (2012), the mentioned differences in force-deflection curves are a result of increased MC and temperature causing softening of the wood structure due to weakening of chemical bonds in the wood cell walls.

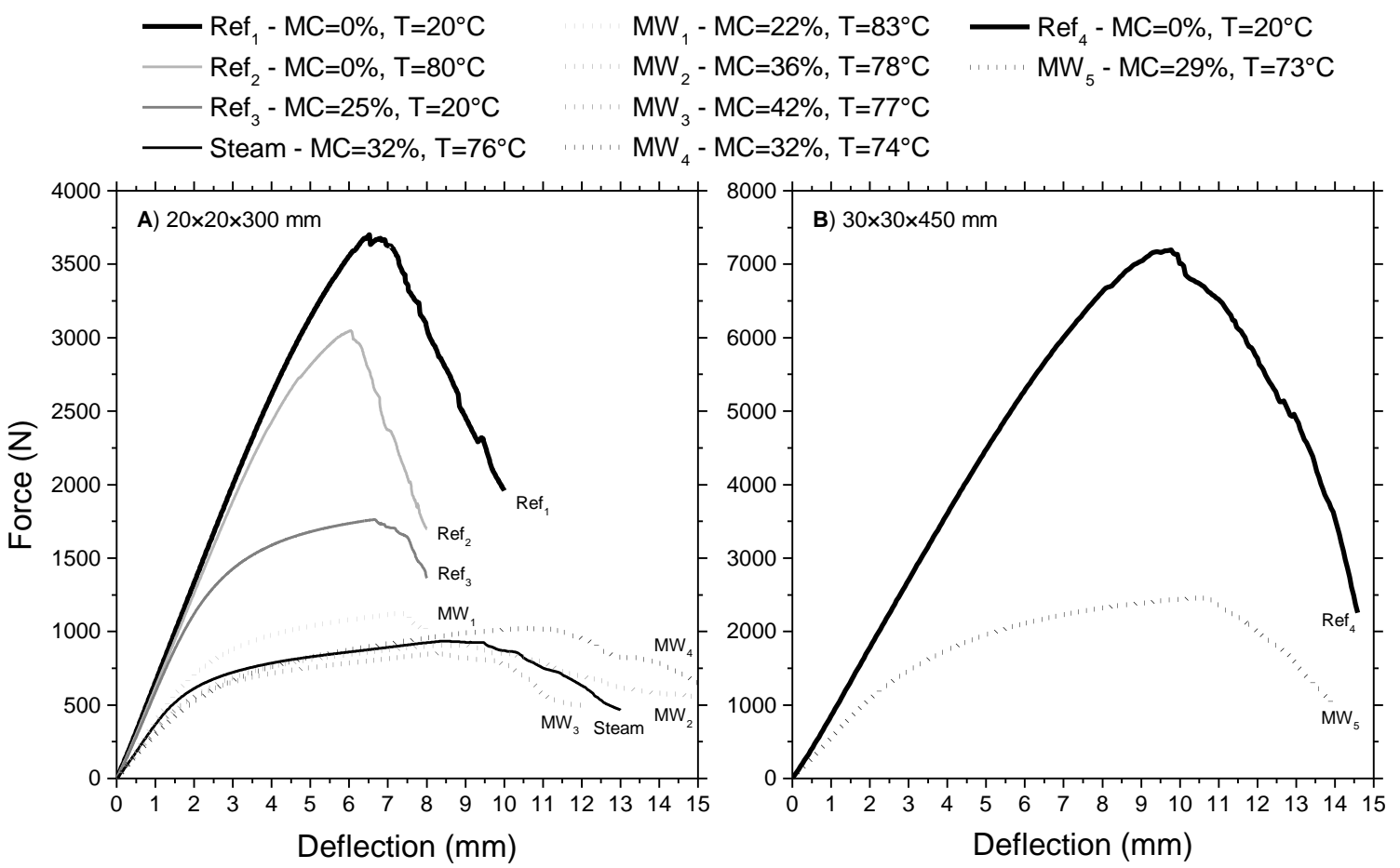

Fig. 1. Average force-deflection curves of individual testing groups

The effect of single factors, i.e., heat $\left(\operatorname{Ref}_{2}\right)$ and $\mathrm{MC}\left(\operatorname{Ref}_{3}\right)$, was observed when compared to oven-dried specimens tested at room temperature $\left(\operatorname{Ref}_{1}\right)$. The MC had a greater plasticization effect than heat. The effect of heat within the range of used temperatures reduced MOR without the wood softening. This finding is supported by previous results reported by Gerhards (1982) and Požgaj et al. (1997). Softening of dry wood starts at higher temperatures. For instance, Shiraishi (1991) stated that oven-dried wood did not show any significant thermal softening until it was heated. Goring (1963) found the first softening of oven-dried wood at temperatures above $200{ }^{\circ} \mathrm{C}$. Chow and Pickles (1971) reported that softening of wood started around $180{ }^{\circ} \mathrm{C}$ and reached the maximum extent at $380{ }^{\circ} \mathrm{C}$. In contrast, the greater plasticization effect of increasing MC can be explained by replacement of chemical bonds between the main components (such as lignin-carbohydrate complexes), especially by forming hydrogen bonds between lignin and water molecules (Sakata and Senju 1975). By forming secondary bonds with the polar groups in the polymer molecules, the moisture reduces the secondary bonding between the polymer chains. The moisture therefore increases the free volume of the system and the 
wood becomes more easily deformable (Birkinshaw 1993). The results show that the combination of heat and moisture in the process of wood plasticization causes significant changes to the plasticity of wood.

The MOR results of the testing groups are presented in Fig. 2. As mentioned above, the effect of MC on its own was greater (reducing MOR by 54\%) than heat on its own (reducing of MOR by 19\%). The amount of MOR reduction due to increased MC is in agreement with Korkmaz and Büyüksari (2019) and Güntekin and Aydin (2013), who reported a $49 \%$ decrease of MOR for wood from sessile oak (Quercus petraea Liebl.) and a 48\% decrease for Turkish red pine (Pinus brutia Ten.). The effect of heat is in agreement with Gerhards (1982), who reported linear trends. According to that research the MOR decreased by $20 \%$ at the temperature of $80{ }^{\circ} \mathrm{C}$.

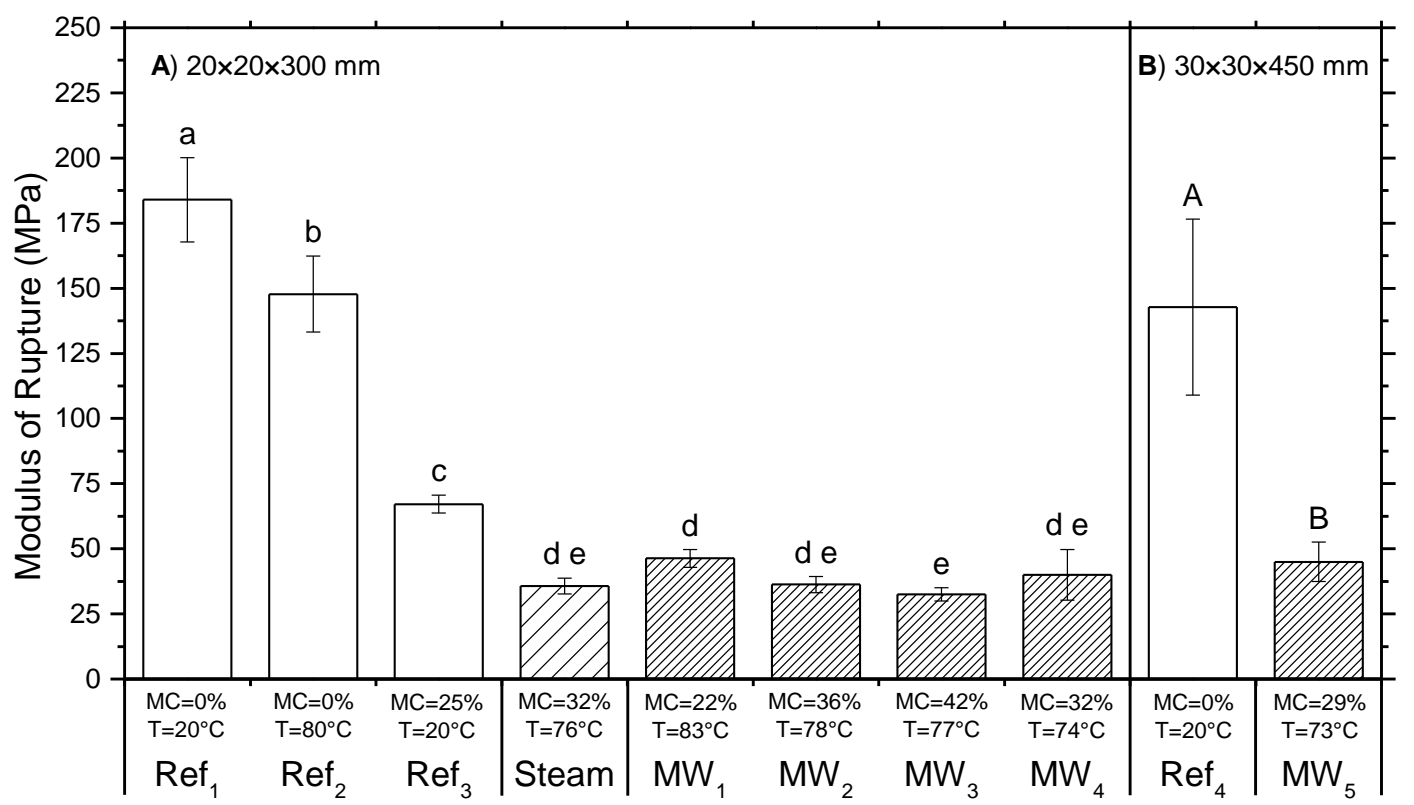

Fig. 2. Modulus of rupture (MOR) for individual testing groups. The same letters within the testing group indicate that the difference between the means is not significant at the 0.05 level.

Generally, the MW and steam-heated specimens showed similar results for MOR. On average, the MOR decreased by about $80 \%$ when compared to Ref $f_{1}$. Minor differences were found within the specimens plasticized by various MW regimes and steam. The only statistically significant difference in terms of MW treatment was found between testing groups $\mathrm{MW}_{1}$ and $\mathrm{MW}_{3}$, where different testing MCs were used (20\% and 40\%). The MOR of the up-scaled specimens (MW5) were decreased by about $69 \%$ when compared to Ref 4 . In fact, the present results show that the suitable plasticization parameters of MW treatment were found. From a practical point of view, when processing plasticized wood, the goal is not to break the element but to shape it more easily. In this context, the reduced MOR can be considered as an undesired plasticity feature; meanwhile, the reduced MOE as a plasticity desired plasticity feature.

The MOE results for the testing groups are shown in Fig. 3. The MOE is considered a main indicator of wood plasticity (Back and Salmén 1982; Irvine 1984). The reference oven-dried specimens $\left(\operatorname{Ref}_{1}\right)$ resulted in a MOE of $14.4 \mathrm{GPa}$. When specimen temperature was increased to $80{ }^{\circ} \mathrm{C}\left(\operatorname{Ref}_{2}\right), \mathrm{MOE}$ decreased on average by $6 \%$. The effect of MC (Ref 3$)$ on wood plasticity was found to be more significant, and MOE decreased on average by 
40\%. Similar results were reported by Korkmaz and Büyüksari (2019), who found a decrease of MOE by $34.9 \%$ for sessile oak (Quercus petraea Liebl.) when wet specimens were compared with air-dried. The effect of MC on bending properties was also studied by Güntekin and Aydin (2013) for Turkish red pine (Pinus brutia Ten.). These authors found that the MOE decreased by $35 \%$, when the MC of tested specimens was increased from 0 to $28 \%$.

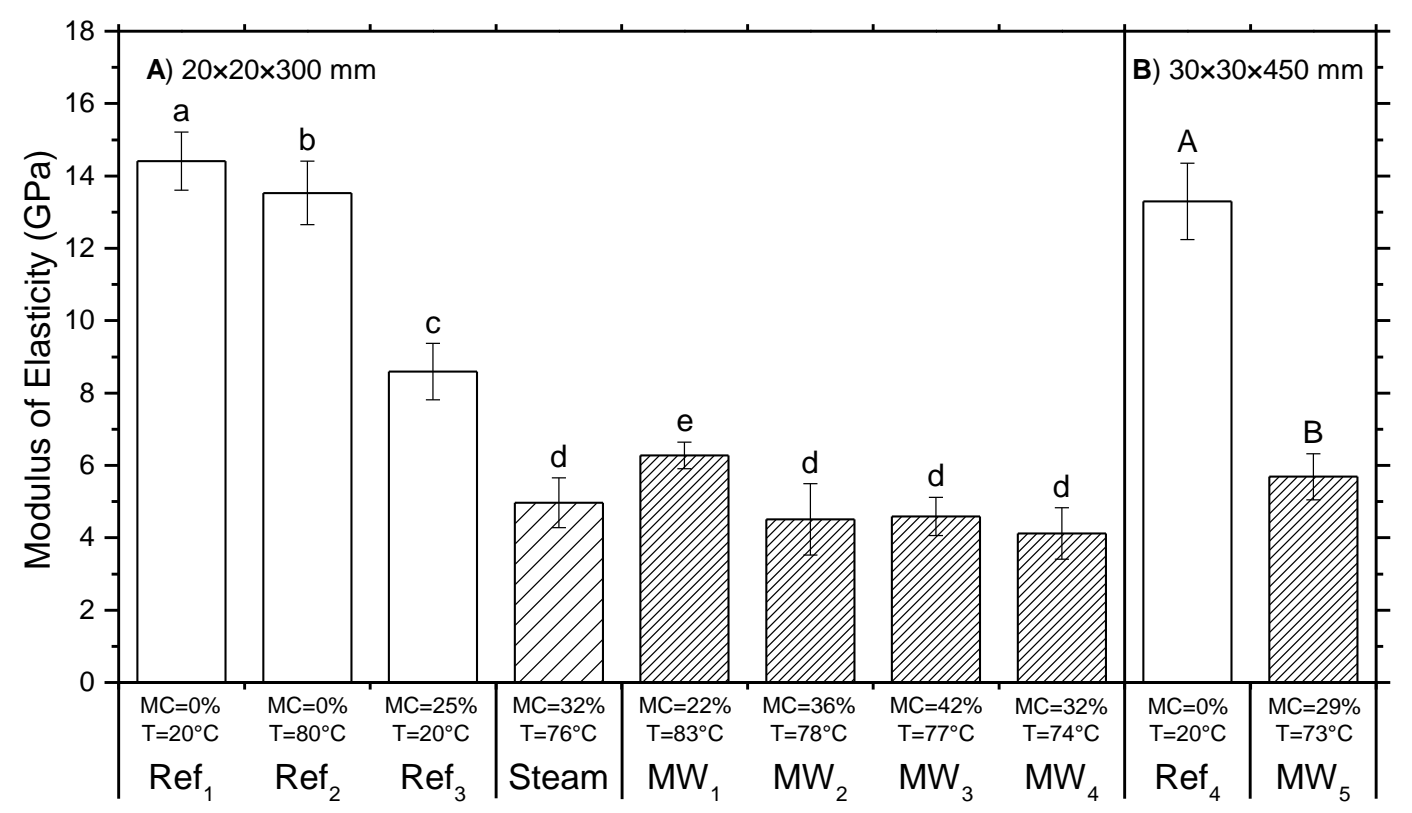

Fig. 3. Modulus of elasticity (MOE) for individual testing groups. The same letters within the testing group indicate that the difference between the means is not significant at the 0.05 level.

It is well known that treatment using a suitable combination of heat and moisture has the greatest effect on wood plasticity (Goring 1963; Grossman 1976; Hillis and Rozsa 1978; Back and Salmén 1982; Irvine 1984; Navi et al. 2002; Rautkari et al. 2009). The presented results indicate that MW and steam heating of moist wood causes a significant increase of temperature within the specimens, which reduces the MOE considerably. Steam treatment, as a conventionally used method for wood plasticization, led to a decrease in MOE of about $65 \%$ when compared to Ref 1 . The most significant increase in wood plasticity was caused by MW treatment at $1.5 \mathrm{~kW}\left(\mathrm{MW}_{2}\right)$ and $3.5 \mathrm{~kW}\left(\mathrm{MW}_{4}\right)$, when the MOE decreased on average by $69 \%$ and $71 \%$, respectively. Similarly, up-scaled specimens heated by MW at $1.5 \mathrm{~kW}$ (MW5) showed a decrease in MOE by about $57 \%$ when compared to up-scaled oven-dried specimens (Ref 4$)$. According to statistical analyses of variance, there were no statistical differences found between $\mathrm{MW}\left(\mathrm{MW}_{2-4}\right)$ and steam-treated specimens. However, the $\mathrm{MW}_{1}$ group showed a statistically significant difference when compared to other testing groups. This difference can be explained by the lower MC of the tested specimens (22\%). From MOE point of view, even though MW-heating reaches the similar values of MOE, it can be a more effective alternative to steaming because it accelerates the process by reducing the plasticizing time and allows the application of a continuous process. Besides low force, the degree of deformability is a crucial prerequisite for shaping plasticized wooden elements without losing their integrity. As an indicator of the degree of deformability, the maximum deflection before failure as a percentage of support span ( $\left.y_{\text {perc }}\right)$ was taken into account. 
The deflection results are depicted in Fig. 4. The deflection of variously plasticized specimens increased in a range of 15 to $68 \%$, when compared to the reference specimens $\left(\operatorname{Ref}_{1}\right)$. The highest $y_{\text {perc }}$ was found for specimens heated by MW in regimes $M_{2}$ and $\mathrm{MW}_{4}$, resulting in $5.1 \%(1.5)$ and $5.0 \%$ (1.0) respectively. Statistically significant differences were found between reference $\left(\operatorname{Ref}_{1-3}\right)$ and $\mathrm{MW}_{2-4}$ and steam-plasticized specimens. Nevertheless, no statistically significant difference in deflection was found within the reference groups ( $\operatorname{Ref}_{1}, \operatorname{Ref}_{2}$ and $\operatorname{Ref}_{3}$ ) or between $\mathrm{MW}_{2-4}$ and steam-treated specimens.

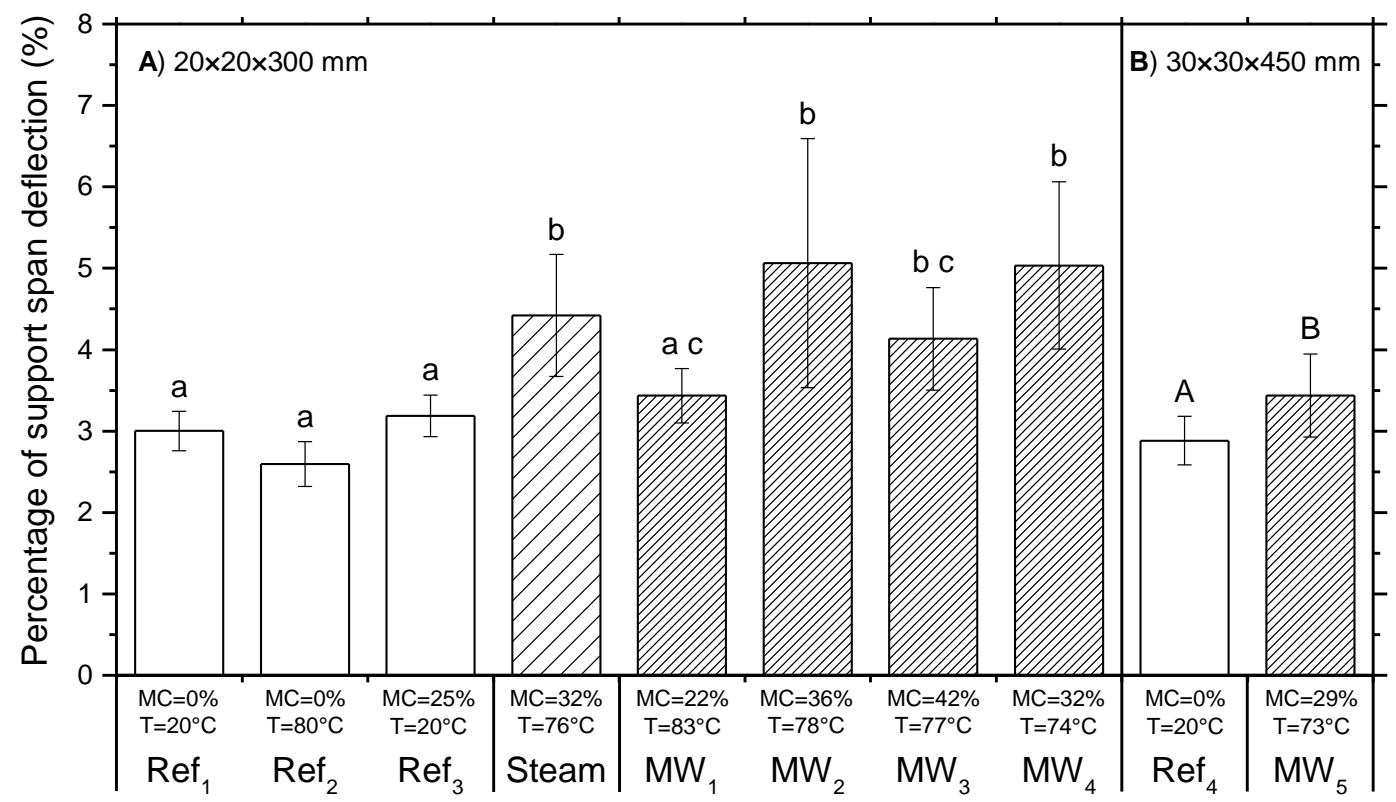

Fig. 4. Maximum deflection as a percentage of support span ( $\left.y_{\text {perc }}\right)$ for individual testing groups. The same letters within the testing group indicate that the difference between the means is not significant at the 0.05 level.

\section{Assessment of Permanent Changes in Micro-Structure and Mechanical Properties}

Scanning electron microscopy revealed that MW treatment according to MW regimes $\left(\mathrm{MW}_{1}\right.$ and $\left.\mathrm{MW}_{4}\right)$ did not influence wood microstructure. Both images of treated beech (Fig. 5b, c) show cross sections with no visible changes compared to the reference (Fig. 5a). No cracks or delamination were found within the internal wood structure or on the surface even at lower magnification. Small size of the specimens together with high permeability of beech wood may have contributed to the fact that the cell wall damage due to MW radiation was not observed.

The results of MOE, MOR, and $y_{\text {perc }}$ for reference $\left(\operatorname{Ref}_{1,4}\right)$ and MW treated $\left(\mathrm{MW}_{1-}\right.$ 5) specimens at an oven-dried state are shown in Table 3. The tested specimens did not exhibit any statistically significant degradation of mechanical properties after selected MW treatments. These results are in agreement with Antti et al. (2001), Liu et al. (2005), and Dömény et al. (2018). It is believed that the greater water permeability of beech wood and a suitable combination of MW heating parameters are the main reasons that delamination of wood cell walls and a consequent decrease of wood strength did not occur in the present study. 

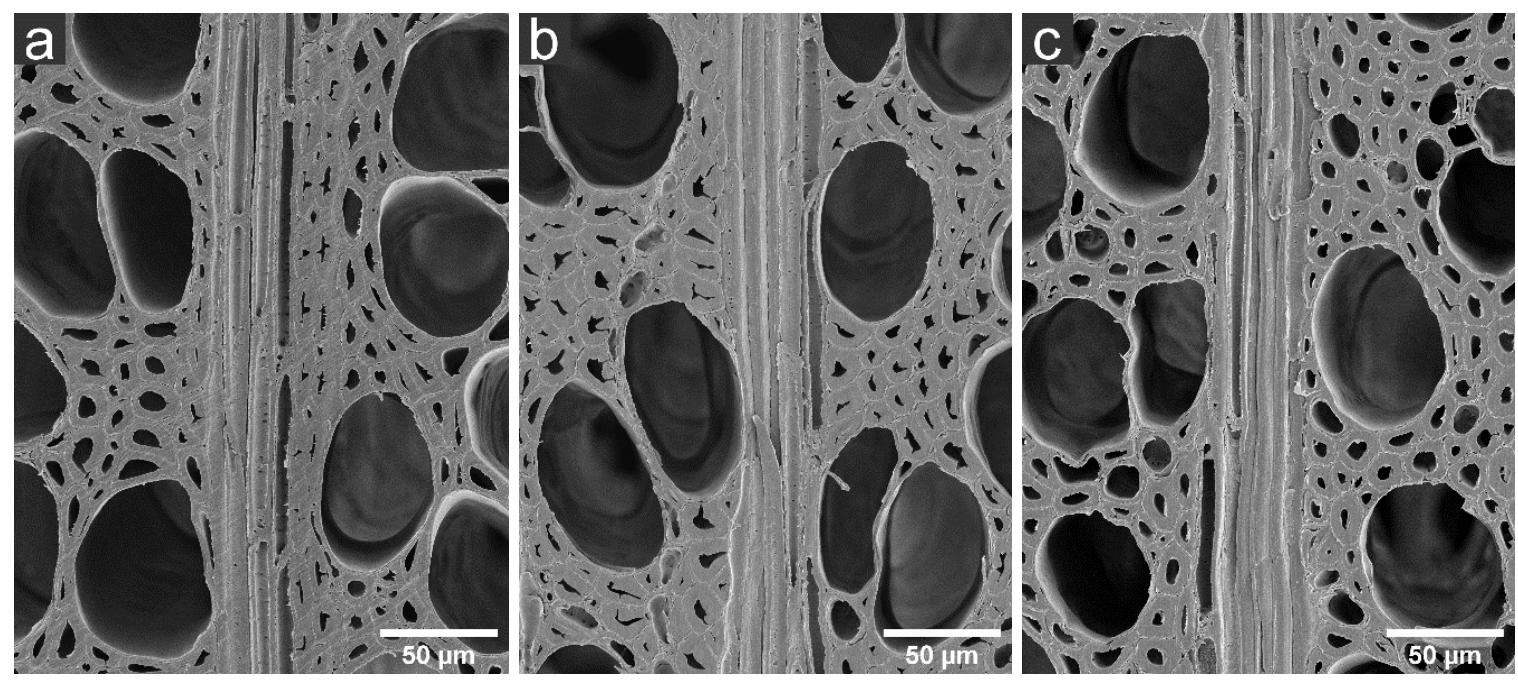

Fig. 5. Scanning electron micrographs of reference beech (a), microwave treatment $\mathrm{MW}_{1}(\mathrm{~b})$, and microwave treatment $\mathrm{MW}_{4}(\mathrm{c})$. Images show cross sections with multiseriate rays and no cracks.

The results show that MW and steam treatments undertaken in the present study produced comparable degrees of plasticization in terms of all of three assessed plasticity features, such as bending strength (MOR), bending stiffness (MOE), and maximum deflection of bent specimens as a percentage of the support span ( $\left.y_{\text {perc }}\right)$. These results are in line with the proposed hypothesis and in agreement with previous studies dealing with wood plasticization for densification purposes published by Dömény et al. (2018). However, it has to be noted that the scale up of MW heating to industrial level may require considerable initial costs.

Table 3. Influence of MW Treatment on Bending Wood Properties: MOE, MOR, and the Percentage of Maximum Deflection from Support Span with Standard Deviations in Parentheses

\begin{tabular}{|c|c|c|c|c|c|c|c|}
\hline \multirow{2}{*}{\begin{tabular}{|l|} 
\\
Testing \\
groups
\end{tabular}} & \multirow[b]{2}{*}{$\begin{array}{c}\rho_{0} \\
\left(\mathrm{~kg} / \mathrm{m}^{3}\right)\end{array}$} & \multirow[b]{2}{*}{$\begin{array}{l}\text { No. of } \\
\text { spec. }\end{array}$} & \multicolumn{2}{|c|}{$\begin{array}{c}\text { Testing } \\
\text { Parameters }\end{array}$} & \multicolumn{3}{|c|}{ Results } \\
\hline & & & $\begin{array}{c}\text { Temp. } \\
\left({ }^{\circ} \mathrm{C}\right)\end{array}$ & $\begin{array}{c}\text { Moisture } \\
\text { content } \\
(\%)\end{array}$ & $\begin{array}{l}\text { Modulus of } \\
\text { elasticity } \\
\text { (GPa) }\end{array}$ & $\begin{array}{l}\text { Modulus of } \\
\text { rupture } \\
\text { (MPa) }\end{array}$ & $\begin{array}{c}\text { Percentage of } \\
\text { maximal deflection } \\
\text { from support span } \\
(\%)\end{array}$ \\
\hline \multicolumn{8}{|c|}{ Standard specimens of dimensions $20 \times 20 \times 300 \mathrm{~mm}$} \\
\hline Ref $_{1}$ & $640(24)$ & 15 & 20 & 0 & $14.4(0.8)$ & $184.0(16.1)$ & $3.0(0.2)$ \\
\hline $\mathrm{MW}_{1}$ & $644(24)$ & 5 & 20 & 0 & $13.9(1.2)$ & $173.3(27.1)$ & $2.9(0.2)$ \\
\hline $\mathrm{MW}_{2}$ & $654(31)$ & 5 & 20 & 0 & $14.1(0.9)$ & $181.1(10.8)$ & $3.0(0.3)$ \\
\hline $\mathrm{MW}_{3}$ & $657(26)$ & 5 & 20 & 0 & $13.8(0.9)$ & $180.5(14.1)$ & $3.1(0.3)$ \\
\hline $\mathrm{MW}_{4}$ & $654(32)$ & 5 & 20 & 0 & $13.5(1.9)$ & $178.4(26.9)$ & $3.1(0.4)$ \\
\hline \multicolumn{8}{|c|}{ Up-scaled specimens of dimensions $30 \times 30 \times 450 \mathrm{~mm}$} \\
\hline Ref $_{4}$ & $618(25)$ & 20 & 20 & 0 & $13.3(1.1)$ & $142.8(33.8)$ & $2.9(0.3)$ \\
\hline $\mathrm{MW}_{5}$ & $621(24)$ & 20 & 20 & 0 & $12.7(1.1)$ & $160.6(19.3)$ & $2.9(0.3)$ \\
\hline
\end{tabular}




\section{CONCLUSIONS}

1. Reference specimens confirmed the different influence of heat and moisture on wood plasticity; the influence of moisture was more significant than the influence of heat, within the range of used temperatures.

2. Plasticization of European beech (Fagus sylvatica L.) by microwave and conventional steam significantly reduced the modulus of rupture (MOR) and modulus of elasticity (MOE), and increased the maximum deflection of testing specimens ( $y_{\text {perc }}$ ).

3. The specimen size had an insignificant influence on wood plasticization; similar results for wood plasticity were obtained.

4. The optimized MW treatments did not influence the mechanical performance of wood.

5. Steaming and MW treatment provided almost the same plasticizing effect. Nevertheless, MW treatment accelerated the process by reducing the plasticizing time (ca. $1.5 \mathrm{~min}$ of MW treatment $v s .60 \mathrm{~min}$ of steaming) and allowing the application of a continuous plasticization process.

\section{ACKNOWLEDGEMENTS}

The study was funded by the Czech Science Foundation (GAČR), Project No. 19$25171 Y$ "Multi-scale Hygro-thermo-mechanical Behavior of Modified Wood-based Materials".

\section{REFERENCES CITED}

Antti, A. L., Jönsson, A., and Nilsson, M. (2001). "The effect of drying method on the mechanical properties of wood: Comparison between conventional kiln and microwave-dried Scots pine," in: Third European Cost E15 Workshop on Wood Drying, Helsinki, Finland.

Baar, J., Brabec, M., Slávik, R., and Čermák, P. (2021). "Effect of hemp oil impregnation and thermal modification on European beech wood properties," Eur. J. Wood Prod. 79, 161-175. DOI: 10.1007/s00107-020-01615-9

Back, E. L., and Salmén, N. L. (1982). "Glass transitions of wood components hold implications for molding and pulping processes," TAPPI 65, 107-110.

Birkinshaw, C. (1993). "Mechanisms of plasticity in wood and wood based materials," in: COST 508-Wood Mechanics, Workshop on Plasticity and Damage, University of Limerick, Ireland.

Börcsök, Z., and Pásztory, Z. (2021). "The role of lignin in wood working processes using elevated temperatures: an abbreviated literature survey," Eur. J. Wood Prod. 79, 511-526. DOI: 10.1007/s00107-020-01637-3

Chow, S., and Pickles, K. J. (1971). "Thermal softening and degradation of wood and bark," Wood and Fibre 3(3), 166-178.

ČSN 490115 (1979). "Drevo. Zist'ovanie medze pevnosti v statickom ohybe," Czech Standards Institute, Prague, Czech Republic.

ČSN 490116 (1986). "Drevo. Metóda zist'ovania modulu pružnosti pri statickom ohybe," 
Czech Standards Institute, Prague, Czech Republic.

Dömény, J., Čermák, P., Koiš, V., Tippner, J., and Rousek, R. (2018). “Density profile and microstructural analysis of densified beech wood (Fagus sylvatica L.) plasticized by microwave treatment," Eur. J. Wood Prod. 76, 105-111. DOI: 10.1007/s00107017-1173-z

Dömény, J., Koiš, V., and Zapletal, M. (2014). “Application of microwave treatment for the plasticization of beech wood (Fagus sylvatica L.) and its densification for flooring system purposes," BioResources 9(4), 7519-7528. DOI: 10.15376/biores.9.4.75197528

Feng, L., and Chen, Z. (2008). "Research progress on dissolution and functional modification of cellulose in ionic liquids," Journal of Molecular Liquids 142(1-3), 15. DOI: 10.1016/j.molliq.2008.06.007

Gašparík, M., and Gaff, M. (2013). "Changes in temperature and moisture content in beech wood plasticized by microwave heating," BioResources 8(3), 3372-3384. DOI: 10.15376/biores.8.3.3372-3384

Gerhards, C. C. (1982). "Effect of moisture content and temperature on the mechanical properties of wood: An analysis of immediate effects," Wood and Fiber Science, 14(1), 4-36.

Goring, D. A. I. (1963). “Thermal softening of lignin, hemicellulose and cellulose," Pulp Paper Mag. Can. 64, 517-527.

Grossman, P. U. A. (1976). "Requirements for a model that exhibits mechano-sorptive behaviour," Wood Sci. Technol. 10, 163-168.

Güntekin, E., and Aydın, T. Y. (2013). "Effects of moisture content on some mechanical properties of Turkish red pine (Pinus brutia Ten.)," in: Proceedings of the International Caucasian Forestry Symposium, Artvin, Turkey, 878-883.

Hansson, L., and Antti, A. L. (2003). "The effect of microwave drying on Norway spruce woods strength: a comparison with conventional drying," J. Mater. Process Tech. 141(1), 41-50. DOI: 10.1016/S0924-0136(02)01102-0

Hillis, W. E., and Rozsa, A. N. (1978). "The softening temperatures of wood," Holzforschung 32, 68-73.

Hong-Hai, L., Qing-Wen, W., Lin, Y., Tao, J., and Ying-Chun, C. (2005). "Modification of larch wood by intensive microwave irradiation," Journal of Forestry Research 16(3), 237-240. DOI: 10.1007/BF02856823

Irvine, G. M. (1984). "The glass transitions of lignin and hemicellulose and their measurement by differential thermal analysis," Tappi 67, 118-121

Jakes, J. E., Hunt, Ch. G., Zelinka, S. L., Ciesielski, P. N., and Plaza, N. Z. (2019). "Effects of moisture on diffusion in unmodified wood cell walls: A phenomenological polymer science approach," Forests 10(12), 1084. DOI: 10.3390/f10121084

Kollmann, F. F. P., and Côté, W. A. (1984). Principles of Wood Science and Technology, Vol I: Solid Wood, Springer, Berlin, Germany. DOI: 10.1007/978-3-642-87928-9

Korkmaz, O., and Büyüksarı, Ü. (2019). "Effects of moisture content on mechanical properties of micro-size oak wood," BioResources 14(4), 7655-7663. DOI: 10.15376/biores.14.4. 7655-7663

Lamason, C., and Gong, M. (2007). "Optimization of pressing parameters for mechanically surface-densified aspen,” For. Prod. J. 57(10), 64-68.

Leiker, M., Aurich, K., and Adamska, M. A. (2005). "Accelerated drying of single hardwood boards by combined vacuum-microwave application," in: 9th Intl. IUFRO 
Wood Drying Conf., Nanjing, China, pp. 185-190.

Li, J., Zhang, L. P., Peng, F., Bian, J., Yuan, T. Q., Xu, F., and Sun, R. C. (2009).

"Microwave-assisted solvent-free acetylation of cellulose with acetic anhydride in the presence of iodine as a catalyst," Molecules 14(9), 3551-3566. DOI: 10.3390/molecules14093551

Liu, H. H., Wang, Q. W., Yang, L., Jiang, T., and Cai, Y. C. (2005). "Modification of larch wood by intensive microwave irradiation," J. For. Res. 16(3), 237-240. DOI: 10.1007/BF02856823

Machado, J. P. (2006). "Effect of microwave treatment on oak compression strength," Silva Lusitana 14(1), 51-58.

Makovíny, I. (2000). "Dielectric and electromagnetic characteristics of beech wood," Wood Research 45(3), 23-34.

Metaxas, A., and Meredith, R. (1983). Industrial Microwave Heating, Institution of Electrical Engineers, London, UK, ISBN 0906048893

Navi, P., Pittet, V., and Plummer, C. J. G. (2002). "Transient moisture effects on wood creep," Wood Sci Technol. 36, 447-462.

Navi, P., and Sandberg, D. (2012). Thermo-Hydro-Mechanical Processing of Wood, EPFL Press, Lausanne, Switzerland.

Norimoto, M., and Gril, J. (1989). "Wood bending using microwave heating," J. Microwave Power EE 24(4), 203-212.

Oliveira, M. E. C., and Franca, A. S. (2002). "Microwave heating of foodstuffs," J. Food Eng. 53(4), 347-359. DOI: 10.1016/S0260-8774(01)00176-5

Oloyede, A., and Groombridge, P. (2000). "The influence of microwave rating on the mechanical properties of wood," Journal of Material Processing Technology 100(1), 67-73.

Plumb, O. A., Spolek, G. A., and Olmstead, B. A. (1985). "Heat and mass transfer in wood during drying," Int. J. Heat Mass Tran. 28, 1669-1678. DOI: 10.1016/00179310(85)90141-3

Požgaj, A., Chovanec, D., Kurjatko, S., and Babiak, M. (1997). Structure and Properties of Wood, Príroda, Bratislava.

Rautkari, L., Kutnar, A., Hughes, M., and Kamke, F. A. (2010). "Wood surface densification using different methods," in: Proceedings of the $11^{\text {th }}$ World Conference on Timber Engineering, Riva del Garda, Italy.

Rautkari, L., Properzi, M., Pichelin, F., and Hughes, M. (2009). "Surface modification of wood using friction," Wood Sci. Technol. 43, 291-299.

Rémond, R., Passard, J., and Perré, P. (2007). "The effect of temperature and moisture content on the mechanical behaviour of wood: A comprehensive model applied to drying and bending," Eur. J. Mech. A-Solid. 26, 558-572.

Rowell, R. M. (ed.) (2005). Chemical Modification of Wood. Handbook of Wood Chemistry and Wood Composites, CRC Press, Boca Raton, FL, USA.

Sakata, I., and Senju, R. (1975). "Thermoplastic behavior of lignin with various synthetic plasticizers,” J. Appl. Polym. Sci. 19, 2799-2810.

Sandberg, D., Haller, P., and Navi, P. (2013). "Thermo-hydro and thermo-hydromechanical wood processing: an opportunity for future environmentally friendly wood products," Wood Mater. Sci. Eng. 8, 1-25.

Seyfarth, R., Leiker, M., and Mollekopf, N. (2003). "Continuous drying of lumber in a microwave vacuum kiln," Proceedings of the $8^{\text {th }}$ International IUFRO Wood Drying Conference, Brasov, Romania, pp. 159-163. 
Shiraishi, N. (1991). Wood and Cellulose Chemistry, Marcel Dekker, New York.

Torgovnikov, G. I. (1993). Dielectric Properties of Wood and Wood-based Materials. Springer-Verlag, Berlin. DOI: 10.1007/978-3-642-77453-9

Torgovnikov, G. I., and Vinden, P. (2009). "High intensity microwave wood modification for increasing permeability," Forest Products Journal 59(4), 84-92.

Vongpradubchai, S., and Rattanadecho, P. (2009). "The microwave processing of wood using a continuous microwave belt drier," Chem. Eng. Process. 48(5), 997-1003. DOI: 10.1016/j.cep.2009.01.008

Zielonka, P., Gierlik, E., Matejak, M., and Dolowy, K. (1997). “The comparison of experimental and theoretical temperature distribution during microwave wood heating," Holz Roh Werkst. 55(6), 395-398. DOI: 10.1007/s001070050253

Article submitted: August 18, 2021; Peer review completed: September 18, 2021;

Revised version received and accepted: October 24, 2021; Published: October 28, 2021. DOI: $10.15376 /$ biores.16.4.8338-8352 